\title{
DETERMINAN KREATIVITAS GURU SEKOLAH DASAR PASCA PENDIDIKAN DAN LATIHAN PROFESI GURU
}

\author{
Slameto \\ Universitas Presiden \\ J1. Ki Hajar Dewantara Kota Jababeka, Cikarang Baru, Bekasi, Indonesia \\ Surel / Posel slameto@ president.ac.id \& 081325107010
}

Submitted: 2018-09-29

Accepted: 2019-05-06

Published: 2019-08-27

\begin{tabular}{ll}
\hline Keywords: & Abstract \\
\hline Creativity, & The 112 Semarang State University Rayon 2017 held 6 stages of \\
Independence, & TPET (Teacher Professional Education and Training which each \\
Understanding & stage consists of 6 classes) for elementary school teachers. One of \\
and discipline, & the goals is to increase the creativity of the participants. The \\
Teachers, & problem in this study is how effective is TPET in increasing teacher \\
Teaching & creativity? Given that there are many factors that influence teacher \\
& creativity as a manifestation of the success of the TPET, in the \\
& management of education and training, one of the determining \\
& factors needs to be chosen; which in this study is limited to the \\
& internal factors of the teacher in question, namely: (1) \\
& independence, (2) teacher's understanding and (3) teacher \\
& discipline after the TPET. The next problem, among others: \\
& independence, Teacher's understanding and (3) discipline, which \\
& factors determine the effectiveness of TPET in increasing teacher \\
& creativity? Data was collected with a rating scale that has been \\
& tested valid and reliable. TPET is effective in shaping teacher \\
& creativity. There is only 1 predictor variable, namely teaching \\
& discipline which is a determinant of teacher creativity. Teacher \\
& discipline influences (positive and significant) on teacher creativity \\
by 35.80\%. Both variables: understanding and independence are & excluded from this model.
\end{tabular}

\section{PENDAHULUAN}

Menurut Munandar (1992) kreativitas guru adalah kemampuan untuk menemukan sejumlah solusi terhadap suatu masalah serta kemampuan untuk melahirkan sesuatu yang baru. Kreativitas guru dapat berupa kemampuan menciptakan sejumlah strategi, metode, model, dan media pembelajaran yang dapat membuat siswa bersemangat untuk belajar. Hal ini sejalan dengan teori psikoanalisa yang memandang kreativitas sebagai hasil mengatasi suatu masalah yang biasanya dimulai sejak di masa anak-anak. Gibbs (dalam Mulyasa, 2012) mengungkapkan bahwa kreativitas dapat dikembangkan melalui tindakan-tindakan berikut: (1) Dikembangkan rasa percaya dan tidak ada perasaan takut, 
(2) Diberikan kesempatan untuk berkomunikasi ilmiah secara bebas dan terarah, (3) Berperan serta pada saat merumuskan tujuan dan evaluasi belajar, (4) Dilakukan pengawasan yang lebih luwes dan demokratis, dan (5) Berperan serta secara aktif dan kreatif dalam keseluruhan proses pembelajaran.

Guilford adalah ahli yang pertama memberikan definisi mengenai kreativitas (Syata, 2018) yang selanjutnya diikuti oleh ahli-ahli berikutnya. Menurut Guilford, ada dua kemampuan berpikir, yaitu berpikir konvergen dan berpikir divergen. Pada berpikir konvergen individu terikat pada informasi yang telah diketahui sebelumnya dan harus mengikuti cara yang telah diketahui sebelumnya dan harus mengikuti cara yang ditentukan untuk memperoleh suatu jawaban yang benar. Pada berpikir divergen individu tidak terlalu terikat pada cara yang telah ditentukan dan pada informasi yang diketahui sebelumnya sehingga memungkinkan individu untuk mencari alternatif baru. Berpikir itulah yang berhubungan dengan kemampuan kreatif karena meliputi kelancaran, fleksibilitas, dan originalitas dalam berpikir.

Sebagai seorang pengajar, guru dituntun untuk mampu menjawab setiap pertanyaan yang dilontarkan oleh para siswa sehingga guru diharapkan mampu berpikir kreatif dan dapat menjawab serta mampu menyelesaikan permasalahan yang ada di kelas maupun di luar kelas.

Dalam pendidikan kreativitas adalah salah satu aspek penting. Kreativitas adalah bentuk pengembarangan diri seseorang. Dalam hal ini seorang guru yang kreatif akan membawa anak didiknya menjadi kreatif. Kreativitas adalah salah satu tujuan dari kurikulum 2013.

Rayon 112 Universitas Negeri Semarang tahun 2017 menyelenggarakan Pendidikan dan Latihan Profesi Guru (PLPG) 6 tahap (setiap tahap terdiri dari 6 kelas) untuk guru SD. Berdasarkan paparan di atas, permasalahan dalam penelitian ini adalah seberapa efektif PLPG yang diselenggarakan oleh Rayon 112 Universitas Negeri Semarang dalam meningkatkan kreativitas guru. Mengingat demikian banyak faktor yang mempengaruhi kreativitas guru sebagai wujud keberhasilan PLPG, dalam menajemen Pendidikan dan Pelatihan - dalam hal ini PLPG - perlu dipilih salah satu faktor penentu; yang dalam penelitian ini dibatasi pada faktor internal guru yang bersangkutan yaitu: (1) kemandirian, (2) pemahaman Guru, dan (3) kedisiplinan guru pasca PLPG. Masalah selanjutnya adalah di antara kemandirian (X1), pemahaman Guru (X2), dan (3) kedisiplinan (X3), faktor manakah yang menjadi penentu efektivitas PLPG dalam meningkatkan kreativitas guru.

Kemandirian berasal dari kata dasar mandiri yang berarti sikap dan perilaku yang tidak mudah tergantung pada orang lain dalam menyelesaikan tugas-tugasnya. Kemandirian adalah hasrat untuk mengerjakan segala sesuatu bagi dirinya sendiri (Kartini, 1987). Tingkat kemandirian seseorang meliputi: memiliki insiatif sendiri, memiliki percaya diri, dan dapat melakukan sesuatu tanpa pertolongan orang lain (Barnadib, 1982). Selanjutnya, komponen-komponen kemandirian guru adalah: melakukan analisis swot, memahami karakteristik peserta didik, membina hasrat peserta didik, memantau kemajuan belajar, menciptakan suasana yang kondusif, merevitalisasi forum musyawarah guru, memberdayakan tenaga kependidikan, dan memantau kemajuan belajar siswa.

Pemahaman adalah kemampuan invidu dalam mengerti atau memahami sesuatu. Memahami berarti mengetahui sesuatu dan mampu melihatnya dalam banyak segi. Selain itu, apabila ia dapat memberikan penjelasan dan meniru hal tersebut dengan kata-katanya sendiri. Winkel (1984) mengemukakan bahwa pemahaman itu mencakup kemampuan untuk mendapatkan makna dan arti dari bahan yang dipelajari. Untuk itu, diperlukan adanya hubungan antara konsep dan makna dari suatu konsep. Anderson et al menyatakan understand is defined as constructing the meaning of instructional messages, including oral, written, and graphic communication. Pernyataan tersebut menjelaskan 
bahwa seseorang dikatakan sudah memahami sesuatu jika mereka mampu mengkonstruksi makna dari pesan-pesan seperti komunikasi lisan, tulisan, dan grafik. Seseorang dikatakan memahami suatu pengetahuan baru jika sudah mampu membangun hubungan antara pengetahuan yang baru diintegrasikan tersebut dengan skema kognitif yang sudah ada padanya. Tingkat pemahaman seseorang terhadap suatu konsep dapat dilihat dari jenis-jenis pemahaman yang dimilikinya.

Dalam proses memahami sesuatu terjadilah proses mengasimilasi sesuatu tersebut ke dalam skema yang sesuai. Seseorang dikatakan memahami konsep ketika ia dapat mengaitkan konsep tersebut ke dalam skema yang dimilikinya. Pada sisi lain, pemahaman sebuah konsep juga dipandang sebagai kemampuan mengaitkan skema-skema tertentu sesuai dengan konsep tersebut dengan atau tanpa mengetahui mengapa skema-skema tersebut saling terkait. Polya (1973) mengemukakan empat tingkat pemahaman, yakni (1) pemahaman mekanikal; (2) pemahaman induktif; (3) pemahaman rasional; dan (4) pemahaman intuitif. Tujuh jenis pemahaman menurut Anderson, et al. (2002) adalah menginterpretasikan, memberikan contoh, mengklasifikasikan, meringkas, menyimpulkan, membandingkan, dan menjelaskan.

Indikator yang menunjukkan pemahaman konsep antara lain sebagai berikut: (1) Menyatakan ulang sebuah konsep, (2) Mengklasifikasikan objek-objek menurut sifatsifat tertentu, (3). Memberikan contoh dan non contoh dari konsep, (4) Menyajikan konsep dalam berbagai bentuk representasi, dan (5) Mengaplikasikan konsep atau algoritma pemecahan masalah

Susanty, et al. (2013) menyatakan bahwa kedisiplinan adalah kesadaran dan kesediaan seseorang menaati semua peraturan perusahaan dan norma-norma sosial yang berlaku. Berdasarkan pengertian diatas disimpulkan bahwa disiplin kerja merupakan suatu sikap, tingkah laku, dan perbuatan yang sesuai dengan peraturan baik tertulis maupun tidak tertulis, dan bila melanggar akan ada sanksi atas pelanggarannya. Lebih lanjut, disiplin adalah usaha untuk membina secara terus-menerus kesadaran dalam bekerja atau belajar dengan baik dalam arti setiap orang menjalankan fungsinya secara efektif (Nawawi,1990). Disiplin berarti kemampuan untuk mengendalikan diri dengan tidak melakukan sesuatu tindakan yang tidak sesuai dan/bertentangan dengan sesuatu yang telah ditetapkan justru sebaliknya melakukan sesuatu yang mendukung dan melindungi sesuatu yang telah ditetapkan (Soedijarto, 1989).

Disiplin kerja sabagai suatu sikap menghormati, menghargai, patuh, dan taat terhadap peraturan-peraturan yang berlaku, baik yang tertulis maupun tidak tertulis serta sanggup menjalankannya dan tidak mengelak untuk menerima sanksi-sanksinya apabila ia melanggar tugas dan wewenang yang diberikan kepadanya. Disiplin kerja (mengajar) adalah suatu alat yang digunakan para manajer untuk berkomunikasi dengan karyawan agar mereka bersedia untuk mengubah suatu perilaku serta sebagai suatu upaya untuk meningkatkan kesadaran dan kesediaan seseorang menaati semua peraturan dan normanorma yang berlaku (Markhamah, et al., 2017). Oleh sebab itu, seorang guru dituntut untuk disiplin dalam mengajar. Disiplin mengajar guru merupakan upaya yang dilakukan oleh setiap guru dalam mengembangkan tugasnya sebagai pendidikan untuk selalu patuh dan taat terhadap peraturan dan tata tertib yang berlaku sehingga memungkinkan kondisi belajar yang efektif. Untuk itu jelas sekali bahwa peranan guru sangat menentukan keberhasilan belajar karena kedudukannya sebagai pemimpin pendidikan di antara siswa pada suatu lembaga pendidikan umumnya dan di dalam kelas khususnya. Adanya disiplin kerja yang tinggi dari guru akan mampu meningkatkan pembelajaran siswa. Hal ini ditunjukkan dengan hasil penelitian yang dilakukan oleh Lewis, et al.(Markhamah, et al., 2017) yang menyimpulkan bahwa strategi disiplin guru telah disarankan untuk menjadi kekuatan yang kuat untuk meningkatkan rasa tanggung jawab siswa di kelas. 
Kemandirian berasal dari kata dasar mandiri yang berarti sikap dan perilaku yang tidak mudah tergantung pada orang lain dalam menyelesaikan tugas-tugasnya. Kemandirian adalah kemampuan untuk melakukan kegiatan sehari-hari dengan sendiri atau dengan sedikit bimbingan atau arahan sesuai dengan tahapan perkembangan dan kapasitasnya. Semakin dini anak untuk berlatih mandiri dalam melakukan tugas-tugas perkembangannya, diharapkan nilai-nilai serta keterampilan mandiri akan lebih mudah untuk dikuasai dan dapat tertanam kuat dalam diri anak. Kemandirian adalah hasrat untuk mengerjakan segala sesuatu bagi dirinya sendiri (Kartini, et al., 1987). Tingkat kemandirian seseorang meliputi: memiliki insiatif sendiri, memiliki percaya diri, dan dapat melakukan sesuatu tanpa pertolongan orang lain (Barnadib, 1982). Komponenkomponen kemandirian guru adalah melakukan analisis swot, memahami karakteristik peserta didik, membina hasrat peserta didik, memantau kemajuan belajar, menciptakan suasana yang kondusif, merevitalisasi forum musyawarah guru, memberdayakan tenaga kependidikan, dan memantau kemajuan belajar siswa.

Tujuan penelitian ini adalah mendeskripsikan tingkat keefektifan PLPG yang diselenggarakan oleh Rayon 112 Universitas Negeri Semarang dalam meningkatkan kreativitas guru; dan menemukan model berpengaruhnya faktor internal guru peserta PLPG yang dalam penelitian ini dipilih kemandirian Guru (X1), Pemahaman (X2) dan kedisiplinan guru (X3) yang menjadi penentu atau determinan efektivitas PLPG.

Determinan berarti faktor yang menentukan; besarnya penentu dinyatakan dengan koefisien determinasi, bertujuan untuk mengukur seberapa jauh kemampuan model dalam menerangkan variasi variabel dependen (efektivitas PLPG). Determinan berguna untuk memprediksi dan melihat seberapa besar kontribusi pengaruh yang diberikan variable independen (X1-3) terhadap variabel dependen (Y yaitu efektivitas PLPG). Dengan analisis regresi ganda model stepwiswe akan diperoleh model pengaruh variable $\mathrm{X}_{1-3}$ yang memiliki korelasi terbesar dengan variabel Y yaitu efektivitas PLPG. Hasil penelitian ini akan sangat bermanfaat bagi pengelola, khususnya dalam pengembangan kualitas supervisi diklat berbasis hasil penelitian.

\section{METODE PENELITIAN}

Penelitian ini dilakukan berdasarkan penilaian dari para alumni PLPG Rayon 112 Universitas Negeri Semarang tahun 2017. Pada tahap I Guru Kelas SD terdiri dari 6 kelas, dipilih 1 kelas secara acak sebagai sampel yang terdiri dari 31 peserta. Berdasarkan rumusan masalah yang diajukan, ternyata penelitian ini adalah penelitian kuantitatif inferensial. Penelitian kuantitatif mengungkapkan hubungan inferensial antara dua atau lebih variabel yang bisa menjelaskan gejala, yang meneliti pengaruh variabel X1 (kemandirian), X2 (pemahaman) dan X3 (kedisiplinan guru) terhadap Y (Kreativitas guru); yang kemudian menemukan variabel penentu tiga variabel independen yang bersangkutan. Penelitian ini dilakukan pada semester 1 tahun 2017/2018. Dalam skala ordinal, variabel kreativitas guru, terdapat satu tingkat yang dominan di antara dua kategori: rendah dan tinggi. Di antara 3 variabel independen, ada penentu/determinan yang berpengaruh positif dan signifikan terhadap kreativitas guru. Dengan demikian, koefisien regresi prediktor penentu (b1) positif dan signifikan. Selanjutnya, hipotesis statistik yang diajukan adalah seperti berikut ini:

H0: b1 = 0 (tidak ada pengaruh penentu/determinan terhadap kreativitas guru)

$\mathrm{H} 1: \mathrm{b} 1 \neq 0$ (ada pengaruh penentu/determinan terhadap kreativitas guru)

Dampak dari prediktor baik secara tunggal maupun ganda yang ditemukan dapat diketahui dengan melihat nilai b dalam variabel penentu yang bersangkutan. Selain itu, 
pentingnya nilai $\mathrm{b}$ akan diuji dengan t-test. Signifikansi $\mathrm{T}$ dapat terlihat pada nilainya. Jika $b$ positif, dan t signifikan pada tingkat kesalahan kurang dari 0,05 , hipotesis (H1) akan diterima.

Data penelitian ini adalah data kuantitatif dalam bentuk angka; Data ordinal adalah data yang dinyatakan dalam bentuk kategori dan/ peringkat. Skala ordinal yang digunakan adalah skala peringkat (Skala Likert) yang terdiri dari pernyataan dan jawaban dengan rendah, sedang, tinggi dan sangat tinggi sesuai dengan tujuan pengukuran. Data dikumpulkan melalui skala self-rating yang terdiri dari 23 item yang telah terbukti valid dan reliabel; Skor validitas 0,325 sampai 0,809, dengan indeks reliabilitas Cronbach Alpha $=0,906$. Data setiap variabel dianalisis dengan distribusi frekuensi, dilanjutkan dengan analisis regresi linier ganda dengan Model Stepwise. Selanjutnya, peneliti mengembangkan model hubungan (model kausal). Pola-pola berpengaruhnya variabel independen (determinan) terhadap variabel terikat yaitu kreativitas guru yang akan diuji dengan uji F pada tingkat 0,05. Perhitungan ini dilakukan dengan berbantu program SPSS versi 24. Dalam pengujian model, koefisien determinan dari variabel independen terhadap variabel dependen dihitung. Hasil perhitungan koefisien determinasi dari 3 variabel independen dalam penelitian ini terhadap variabel dependen sebesar koefisien adjusted $\mathrm{R} 2$. Jika signifikansi $\mathrm{r}$ kurang dari atau sama dengan 0,05, maka model dinyatakan signifikan karena $\mathrm{X}_{1-3}$ (yang terpilih) mempengaruhi $\mathrm{Y}$, sebesar koefisien adjusted $\mathrm{R}^{2}$.

\section{HASIL DAN PEMBAHASAN}

\section{Deskripsi variabel}

Setelah data dijaring menggunakan self-rating scale yang terdiri dari 23 item untuk guru lulusan PLPG, dianalisis secara deskriptif dibantu program SPSS for windows version 24 diperoleh hasil dalam bentuk Tabel 1 .

Tabel 1. Indeks Statistik Variabel Penelitian

\begin{tabular}{lccccc}
\hline \multicolumn{1}{c}{ Var } & Mean & Median & Std. Deviation & Minimum & Maximum \\
\hline Kemandirian & 1,8387 & 2,0000 & 0,37388 & 1,00 & 2,00 \\
\hline Pemahaman & 1,8387 & 2,0000 & 0,37388 & 1,00 & 2,00 \\
\hline Disiplin & 1,8710 & 2,0000 & 0,34078 & 1,00 & 2,00 \\
\hline Kreativitas & 1,8387 & 2,0000 & 0,37388 & 1,00 & 2,00 \\
\hline
\end{tabular}

Berdasarkan hasil analisis deskriptif tersaji pada tabel 1 di atas, sebagian besar responden (alumni/ guru peserta PLPG) memiliki penilaian terhadap kemandirian $\left(\mathrm{X}_{1}\right)$ pada aras tinggi, demikian juga Pemahaman $\left(\mathrm{X}_{2}\right)$ pada aras tinggi, dan kedisiplinannya $\left(\mathrm{X}_{3}\right)$ pada aras tinggi; penguasaan kreativitas guru $(\mathrm{Y})$ pada aras tinggi.

\section{Seberapa efektif PLPG yang diselenggarakan oleh Rayon 112 Universitas Negeri Semarang dalam meningkatkan kreativitas guru?}

Terkait dengan permasalahan pertama, untuk mengetahui efektivitas PLPG yang diselenggarakan oleh Rayon 112 Universitas Negeri Semarang dalam meningkatkan kreativitas guru dilakukan analisis deskriptif yang hasilnya seperti tersaji pada tabel 2 berikut ini. 
Tabel 2 Deskripsi Kreativitas Guru SD pasca PLPG

\begin{tabular}{cccccc}
\hline & Frequency & Percent & Valid Percent & Cumulative Percent \\
\hline \multirow{2}{*}{ Valid } & 1,00 & 5 & 16,1 & 16,1 & 16,1 \\
\cline { 2 - 5 } & 2,00 & 26 & 83,9 & 83,9 & 100,0 \\
\cline { 2 - 5 } & Total & 31 & 100,0 & 100,0 & \\
\hline
\end{tabular}

Sekalipun tidak ada data pra PLPG tentang kreativitas guru SD peserta PLPG, Berdasarkan tabel 2 di atas, bisa diprediksi ternyata sebagian besar guru SD pasca PLPG memiliki kreativitas yang tinggi (83,9\%). Itu berarti PLPG yang diselenggarakan oleh Rayon 112 Universitas Negeri Semarang sangat efektif menghasilkan luaran guru yang kreatif.

\section{Uji Hipotesis}

Analisis selanjutnya adalah untuk mengetahui apakah ada dari ketiga variabel bebas $\left(\mathrm{X}_{1-3}\right)$ yang menjadi determinan terhadap kreativitas guru (Y). Jika benar, terdapat berapa model, dan berapa besar pengaruhnya? Hasil uji hipotesis menggunakan analisis regresi ada pada Tabel 3 berikut ini.

Tabel 3 Model Summary Determinan Kreativitas Guru SD pasca PLPG

\begin{tabular}{ccccc}
\hline Model & $\boldsymbol{R}$ & $\boldsymbol{R}$ Square & Adjusted $\boldsymbol{R}$ Square & $\begin{array}{c}\text { Std. Error of the } \\
\text { Estimate }\end{array}$ \\
\hline 1 & $0,616^{\mathrm{a}}$ & 0,380 & 0,358 & 0,29953 \\
\hline
\end{tabular}

a. Predictors: (Constant), Disiplin

Berdasarkan hasil uji hipotesis melalui analisis regresi model Stepwise seperti tersaji pada tabel 3 di atas, ternyata diperoleh hanya 1 Model; Model 1 disiplin kerja guru $\left(\mathrm{X}_{3}\right)$ menjadi determinan yang berpengaruh terhadap krearivitas guru $(\mathrm{Y})$ : diperoleh $\mathrm{R}=0,616$ dan Adjusted $\mathrm{R}$ Square $=0,358$ atau 35,8\%. Dengan demikian, hipotesis yang menyatakan terdapat penentu kreativitas guru terdukung data. Untuk menentukan apakah model ini signifikan, dapat diperiksa pada Tabel 4 berikut ini!

Tabel 4. Anova ${ }^{a}$ berpengaruhnya determinan terhadap kreativitas guru

\begin{tabular}{|c|c|c|c|c|c|c|}
\hline & Model & Sum of Squares & $d f$ & Mean Square & $F$ & Sig. \\
\hline \multirow[t]{3}{*}{1} & Regression & 1,592 & 1 & 1,592 & 17,741 & $0,000^{\mathrm{b}}$ \\
\hline & Residual & 2,602 & 29 & 0,090 & & \\
\hline & Total & 4,194 & 30 & & & \\
\hline
\end{tabular}

a. Dependent Variable: Kreativitas

b. Predictors: (Constant), Disiplin

Berdasarkan Tabel 4 anova seperti di atas, ternyata diperoleh hanya 1 Model; Model 1 kedisiplinan guru $\left(\mathrm{X}_{3}\right)$ berpengaruh terhadap kreativitas $(\mathrm{Y})$ : diperoleh $\mathrm{F}=17,741$ pada tingkat signifikansi 0,000 . Dengan demikian, hanya 1 variabel prediktor yaitu kedisiplinan berpengaruh (positif dan signifikan) menjadi determinan kreativitas guru (Y). Kedua variabel yaitu: kemandirian $\left(\mathrm{X}_{1}\right)$ dan pemahaman $\left(\mathrm{X}_{2}\right)$ dikeluarkan dari model; dengan 
kata lain, kemandirian dan pemahaman guru tidak menjadi penentu kreativitas guru paska PLPG terdukung data.

\section{Pembahasan}

Penelitian ini berhasil menemukan bahwa PLPG Rayon 112 Universitas Negeri Semarang efektif dalam membentuk kreativitas guru. Capaian guru dalam penguasaan kreativitas ini sebagian besar pada aras tinggi. Capaian ini sejalan dengan Kompasiana (2017) sebuah ide kreatif seorang guru sangat diperlukan untuk dapat mengubah situasi pembelajaran menjadi menarik dan efektif sekaligus mengajak siswa lebih aktif. Ciri-ciri guru yang kreatif (Ranis, 2013) adalah: (1) berpikir inovatif, (2) percaya diri, (3) tidak gaptek, (4) materi pelajaran yang diberikan menjadi mudah dimengerti, (5) terus belajar dan belajar, (6) cerdas dalam menemukan talenta anak didiknya, (7) kooperatif, ((8) pandai memanfaatkan "apa yang ada", (9) bisa menerima kritik, (10). mengajar dengan cara menyenangkan, (11) membentuk kekhasan sekolah, (12) banyak relasi, dan (13) tidak "melulu" berorientasi pada uang dalam berkarya.

Untuk menjadi guru yang kreatif (Nurhasriyoni, 2018) dapat diterapkan prinsip "FORCHILDREN", yaitu fleksibel, optimis, respek, cekatan, humoris, inspiratif, lembut, disiplin, responsif, empatik, dan ngefriend. Guru perlu berupaya untuk menerapkan prinsip ini supaya tumbuh percaya diri dalam melaksanakan kewajiban menjadi guru. Selain itu, guru menerapkan motto "not only teach, but also touch" guru tidak hanya mengajar, tetapi juga menyentuh hati para peserta didiknya sehingga nilai yang diperoleh guru sangatlah bermakna.

Hasil penelitian ini menemukan hanya kedisiplinan guru yang berpengaruh terhadap kreativitasnya. Dengan kata lain, kedisiplinan guru menjadi determinan kreativitas guru. Temuan model berpengaruhnya kedisiplinan guru terhadap kreativitasnya ini sepanjang penelusuran di Google Cendekia baik yang berbahasa Indonesia maupun Bahasa Inggris belum ditemukan; Dengan demikian, kedisiplinan guru menjadi kunci utama untuk meningkatkan kreativitas guru. Upaya manajerial yang dapat dilakukan adalah menerapkan 5 gaya (Tomal, 1998), yaitu: enforcer (penegak), abdicator (penculik), supporter (pendukung), compromiser (kompromi), dan negotiator (negosiator) dalam menegakkan aturan dan mendukung siswa. Hasil penelitiannya menunjukkan bahwa para guru yang efektif memanfaatkan kelima gaya disiplin dalam mendisiplinkan siswa. Guru yang menggunakan gaya disiplin negosiator menunjukkan tingkat yang paling tinggi, Guru yang menegakkan dan mendukung, mengambil pendekatan win-win untuk pendisiplinan siswa; mereka memiliki paling sedikit kesulitan dalam menangani masalah disiplin siswa. Gaya negosiator dapat menawarkan pendekatan yang paling efektif dalam penanganan disiplin kelas; [bandingkan dengan: Chiu, et al., 1997, Lee, et al., 2005), dan Kaya, et al., 2010)]. Berdasarkan paparan ini, ternyata disiplin juga merupakan prinsip kreativitas; dengan demikian, wajarlah kalau disiplin menjadi determinan kreativitas guru, terlebih pasca sertifikasi.

Selanjutnya, berdasarkan hasil analisis di atas, variabel kemandirian guru dalam mengajar dan pemehamannya dikeluarkan dari model; ini berarti bahwa baik kemandirian guru dalam mengajar maupun pemehamannya bukan determinan kreativitas guru. Temuan ini menyanggah hasil penelitian Dalimunthe (2015) yang menyatakan bahwa Guru yang mandiri mampu mengembangkan kreativitas; Selain itu, hasil penelitian ini sejalan dengan penelitian Mayasari (2014) yang menyatakan bahwa pemehaman guru tidak berpengaruh terhadap tingkat kreativitasnya. 


\section{SIMPULAN}

Berdasarkan sajian hasil penelitian di atas, disimpulkan bahwa PLPG efektif dalam membentuk kreativitas guru. Terdapat hanya 1 variabel prediktor yaitu disiplin dalam mengajar yang menjadi determinan kreativitas guru. Sepanjang penelusuran dengan Google Cendekia, tidak ditemukan hasil penelitian yang menyatakan bahwa kedisiplinan guru dalam mengajar mempengaruhi atau menjadi determinan kreativitas guru. Kedisiplinan guru berpengaruh (positif dan signifikan) terhadap kreativitas guru sebesar $35,80 \%$. Kedua variabel adalah pemahaman dan kemandirian dikeluarkan dari model ini; dengan kata lain, pemahaman dan kemandirian tidak menjadi penentu kreativitas guru (pasca PLPG) terdukung data.

Dengan ditemukannya kedisiplinan sebagai determinan kreativitas guru ini, pengembangan kompetensi guru yang terfokus pada kreativitasnya hanya akan berhasil jika dimulai dengan penegakan disiplin guru yang bersangkutan; Upaya manajerial yang dapat dilakukan adalah menerapkan 5 gaya pendisiplinan (enforcer, abdicator, supporter, compromiser, dan negotiator). Model yang ditemukan dalam penelitian ini akan sangat bermanfaat bagi manajemen mutu pendidikan dalam kerangka efektivitas dan produktivitas Pendidikan Profesi Guru berbasis kreativitas guru selama proses pendidikan dan/pelatihan.

\section{DAFTAR PUSTAKA}

Anderson, L. W., Krathwohl, D. R., Airasian, P. W., Cruikshank, K. A., Mayer, R. E., Pintrich, P. R., . \& Wittrock, M. C. (2001). A taxonomy for learning, teaching, and assessing: A revision of Bloom's taxonomy of educational objectives, abridged edition. White Plains, NY: Longman.

Barnadib, Sutari Imam. (1982). Pengantar Ilmu Mendidik Anak-anak. Yogyakarta: Institut Press IKIP Yogyakarta.

Chiu, L. H., \& Tulley, M. (1997). Student preferences of teacher discipline styles SOURCE: Journal of Instructional Psychology. 24:168-75

Dalimunthe, R. A. A. (2015). Strategi dan Implementasi Pelaksanaan Pendidikan Karakter dan Bakat, Gramedia Pustaka Jakarta,

Kartini; Dali Gulo. (1987). Kamus Psikologi. Bandung: CV. Pionir Jaya.

Kaya, S., Lundeen, C., \& Wolfgang, C. H. (2010). Discipline orientations of preservice teachers before and after student teaching. Teaching Education, 21(2): 157-169.

Lee, S., \& Powell, J. V. (2005). Using computer-based technology to determine emergent classroom discipline styles in preservice teacher education. Journal of Educational Technology Systems, 34(1): 83-110.

Markhamah; Muhibbin, A. (2017). Pembinaan Disiplin Kerja Guru SD Negeri Cengklik II Surakarta. Doctoral dissertation, Universitas Muhammadiyah Surakarta.

Mayasari, R. (2014). Gambaran tingkat pengetahuan tumbuh kembang anak, self efficacy mengajar dan kreativitas guru raudhatul atfhal di Sulawesi Tenggara. Al-Izzah: Jurnal Hasil-Hasil Penelitian, 9(2): 155-168.

Mulyasa, E. (2006). Menjadi guru profesional: menciptakan pembelajaran kreatif dan menyenangkan, Bandung: Remaja Rosdakarya 
Slameto, Determinan Kreativitas Guru Sekolah ...

Munandar, Utami. (2002). Kreatif dan Keberbakatan, Strategi Mewujudkan Potensi Kreatif. Gramedia Pustaka Utama.

Nawawi. H. (1990). Metode Penelitian Bidang Sosial, Yoyakarta: Gajah Mada University Press.

Nurhasriyoni, (2018). Pentingnya Menjadi Guru Kreatif Dalam Proses Belajar Mengajar. http://www.tanjungpinangpos.co.id/

Polya, G., (1973), How To Solve It, Second Edition, Princeton University Press, Princeton, New Jersey.

Ranis, Bunda. (2013), Kenapa guru harus kreatif dalam mengajar?, https://bimbaaiueo.com/kenapa-guru-harus-kreatif-dalam-mengajar/

Soedijarto, (1989). Pendidikan Sebagai Sarana Reformasi Mental dalam Upaya Pembangunan Bangsa, Jakarta: Balai Pustaka

Susanty, A., \& Baskoro, S. W. (2013). Pengaruh motivasi kerja dan gaya kepemimpinan terhadap disiplin kerja serta dampaknya pada kinerja karyawan (studi kasus pada PT. PLN (Persero) apd semarang. J@ ti Undip: Jurnal Teknik Industri, 7(2): 7784.

Syata, W. M. (2018). "Pengaruh Penggunaan Multimedia dan Kreativitas Guru terhadap Prestasi Belajar Ekonomi Pendidik pada Jurusan IPS SMA Negeri 5 Makassar". Doctoral dissertation, Universitas Negeri Makassar.

Tomal, D. R. (1998). A five-styles teacher discipline model. https://eric.ed.gov/?id= ED425158

Winkel. (1984). Psikologi Pendidikan dan Evaluasi Belajar. Jakarta: Gramedia. 